accepted a commission to study the dipterous insects of the temperate zone of the southern hemisphere, a study which still occupied his leisure hours up to the day of his death.

From Belgium Tonnoir went to New Zealand, where he worked at the Cawthron Institute, the Canterbury Museum, and the Canterbury University College, until 1929, when he joined the staff of the Division of Economic Entomology of the Australian Council for Scientific and Industrial Research in Canberra. During the past ten years he has been closely associated with research on biological control of insect pests and weeds, and has also played a prominent part in the development of an intensive study of the grasshoppers in Australia. Mr.Tonnoir's numerous papers on lesser-known families of the Diptera do not adequately reflect his remarkable knowledge of insects, although they are a record of the thoroughness of his work and his outstanding ability as a taxonomist.

Tonnoir's death removes a colourful personality and a delightful colleague, but our sadness is tem. pered by the knowledge that he died as he would have wished, peacefully in his sleep as he rested in the shade of a tree, after a morning's collecting in the bush.

A. J. Nicholson.

\section{Mr. H. G. Newth}

Mr. H. G. Newth, whose death at the age of fiftyfour occurred on February 17 after a long illness, went to school in Worcester and then entered the Royal College of Science, London. There he studied zoology under Adam Sedgwick and Mr. Clifford Dobell, and then became demonstrator in zoology for Prof. E. W. MacBride, a post which he held until the War of 1914-18. From 1920 onwards, he was lecturer in zoology in the University of Birmingham.

The early death of Mr. Newth will be deeply regretted by his friends in zoological and other circles, for he had a personal charm which endeared him to his colleagues and his students, generations of whom remember his clear lectures and skilled help in the laboratory. Advanced students profited especially from his embryological teaching, embodying practical experimental work on modern lines.

Mr. Newth was a master of microscopical technique and was always more than willing to help other research workers in the laboratory. His own original contributions included work on the embryology of Cucumaria and of Astropecten, on the development of Amphioxus, and on the swarming of Vorticella. Perhaps his most important research was on the mode of feeding of the ammocœte, which he showed to be different from that of any other animal (NATURE, $126,94 ; 1930)$. Mucus secreted by the endostylethyroid is moved by cilia forwards and up the peripharyngeal grooves, from which it is freed as a cone of mucous strands, uniting behind to form a mucous cord which lies free in the middle of the pharynx. This cord is continuously sucked back into the gullet by cilia in the latter. Food particles drawn into the mouth with the respiratory water current, which is maintained by muscular movements of the pharynx and of the velum, are caught in the cone of mucous strands and passed back into the gullet in the mucous cord.

H. M. F.

\section{Prof. C. Tangl}

Prof. Charles Tangl, of the University of Budapest, died on January 10 in his seventy-first year. He received his early training in physics at the University of Budapest, where he was student, and later assistant and collaborator of Prof. Eötvös. He was appointed in 1901 as Privat-Dozent and in 1903 as professor of experimental physics at the University of Kolozsvár. In 1917 he became professor of physics at the Polytechnic in Budapest, and in 1921 he succeeded Eötvös in the chair of experimental physics at the University of Budapest. He was a member and president of Section III of the Hungarian Academy of Science.

Tangl's interests lay in three different branches of physical research. His early work was devoted to the study of the effect of magnetic fields upon the mechanical properties of solid bodies, especially of the effect upon elasticity. Then in several papers he published the results of his investigations upon the variation of the dielectric constant of liquids with pressure and temperature. These experiments, carried out with great care and accuracy, furnished very reliable values of the dielectric constants which are frequently cited. In a third line of work he applied quite new methods to investigate the forces at the contact surface of solid and liquid bodies; the determination of the contact force between platinum and water, in particular, should be mentioned.

Tangl was a man of outstanding personality and wide knowledge. A thoroughly critical judgment was combined with great kindness; he was a helpful friend to all who needed his advice. M. Forró.

WE regret to announce the following deaths :

Prof. F. Emich, emeritus professor of chemistry in the Polytechnic Institute, Graz, an authority on microchemistry, on January 22, agad seventy-nine years.

Sir Thomas Heath, K.C.B., K.C.V.O., F.R.S., an authority on Greek mathematics, on March 16, aged seventy-eight years.

Prof. A. G. Högbom, emeritus professor of geology in the University of Uppsala, on January 19, aged eighty-four years.

Prof. Bernhard Lehmann, emeritus professor of chemistry and director of the Institute of Hygiene in the University of Würzburg, on January 28, aged eighty-two years.

Prof. W. C. Morgan, professor of chemistry in the University of California at Los Angeles, on February 9 , aged sixty-five years.

Dr. A. J. R. O'Brien, C.M.G., chief medical adviser to the Colonial Office, on March 9, aged fifty-six years. 